\title{
Levels of Interorganizational Trust in Construction Projects: Empirical Evidence
}

\author{
Albertus Laan ${ }^{1}$; Hans Voordijk²; Niels Noorderhaven ${ }^{3}$; and Geert Dewulf ${ }^{4}$
}

\begin{abstract}
Interorganizational trust is important, especially in an industry characterized by constantly changing combinations of organizations working on temporary projects, as in the construction industry. However, little is known about the factors influencing trust in this setting. This study aims to begin to fill that gap by studying trust in their counterparts, as expressed by principals and contractors engaged in construction projects. The findings show that the temporal embeddedness of the relationship (past and expected future relationships) is strongly positively related to the level of trust. Moreover, this study finds that the tendering procedure used and the delivery system employed influence the level of trust of the contractor but not that of the principal. Practical implications and suggestions for further research are drawn from these results. DOI: 10.1061/(ASCE)CO.1943-7862.0000495. () 2012 American Society of Civil Engineers.
\end{abstract}

CE Database subject headings: Contracts; Surveys; Construction management; Netherlands.

Author keywords: Trust; Principals; Contractors; Survey; Construction projects; The Netherlands.

\section{Introduction}

In the last few decades, research on interorganizational trust has received increasing attention. Whereas interorganizational trust remained a narrow niche subject until the late 1980s, it has now become a central issue in the domain of management research (Rousseau et al. 1998; Bachmann 2001; McEvily et al. 2003; Bijlsma-Frankema and Costa 2005; Costa and Bijlsma-Frankema 2007). Because neither formal contracts nor informal agreements are sufficient guarantees of efficient and effective relationships between business partners, the trust phenomenon has become a key concept in analyzing the processes, structures, and performance of interorganizational relationships. Numerous articles and books (Kramer and Tyler 1996; Lane and Bachmann 1998; Nooteboom 2002; Bachmann and Zaheer 2006) have appeared. In the area of construction engineering and management, interorganizational trust is also increasingly receiving attention (Jin and Ling 2005; Kadefors 2004; Khalfan and McDermott 2007; Girmscheid and Brockmann 2010; Lau and Rowlinson 2009; Wong et al. 2005; Yiu and Lai 2009).

A specific context that challenges the conventional understanding of the dynamics of interorganizational trust is formed by the relationships between business partners in the construction

\footnotetext{
${ }^{1}$ Researcher, Univ. of Twente, Construction Management and Engineering, P.O. Box 217, 7500 AE Enschede, Netherlands. E-mail: A.Laan@hhm.nl

${ }^{2}$ Associate Professor, Univ. of Twente, Construction Management and Engineering, P.O. Box 217, 7500 AE Enschede, Netherlands (corresponding author). E-mail: j.t.voordijk@utwente.nl

${ }^{3}$ Professor, Tilburg Univ., Organisation and Strategy, P.O. Box 90153, 5000 LE Tilburg, Netherlands. E-mail: n.g.noorderhaven@uvt.nl

${ }^{4}$ Professor, Univ. of Twente, Construction Management and Engineering, P.O. Box 217, 7500 AE Enschede, Netherlands. E-mail: g.p.m.r .dewulf@utwente.nl

Note. This manuscript was submitted on July 8, 2010; approved on September 29, 2011; published online on October 3, 2011. Discussion period open until December 1, 2012; separate discussions must be submitted for individual papers. This paper is part of the Journal of Construction Engineering and Management, Vol. 138, No. 7, July 1, 2012. CASCE, ISSN 0733-9364/2012/7-821-831/\$25.00.
}

industry. In this project-based industry, relationships between organizations are established for a shared and relatively clear purpose: The realization of a building project within a well-defined period of time. The specific characteristics of the construction industry make the development of interorganizational trust in this context a fascinating puzzle. On the one hand, parties involved in a construction project have no time to engage in the lengthy processes that usually contribute to the development of trust in more enduring organizational forms. On the other hand, independent strangers faced with a deadline also have to handle issues of vulnerability and risk adequately to end up with a satisfactory project performance. Therefore, they may have to act as if trust is present, although the trustworthiness of a business partner has yet to be proven.

It has been suggested that project partners import expectations of trust from comparable settings with which they are familiar (Kanawattanachai and Yoo 2002; Meyersonet al. 1996). A certain level of trust already may exist at the start of a relationship (McKnight 1998). Past experiences and also prospects of future exchange play an important role in determining if and to what extent a partner can be trusted (Axelrod 1984; McAllister 1995; Rousseau et al. 1998). This involves conscious predictions of the other's trustworthiness on the basis of prior contact. Trust especially becomes an issue when things go wrong (Nooteboom 2002; Welling 2006). It has also been stated that trust in projects is strongly influenced by the tender procedure used and the delivery system adopted (Kadefors 2004; Lui and Ngo 2004; Zaghloul and Hartman 2003).

The major objective of this study is to explore to what extent the level of trust between the principal and contractor organizations of construction projects varies according to their history of working together and their prospects of working together again, the tender procedures used, and the contracts adopted. By making use of a survey, this paper explores how the level of trust between the principal and contractor organizations in a large-scale sample of construction projects varies according to these variables.

The outline of this article is as follows. First, the factors that influence the level of trust in projects are examined. Second, the methods used for data collection and data analysis are explained. Third, the authors focus on how the history of working together and 
the prospects of working together again influences the level of trust in construction projects. The next section consists of an analysis of how trust relates to the tender procedure used and the delivery system adopted. Finally, the results are discussed, and conclusions are drawn from this study.

\section{Trust in Project-Based Industries}

This section starts by presenting different definitions of trust. It is followed by a discussion of the factors that influence the level of trust in projects in general: The history of working together and the prospects of working together again, the tender procedure used, and the delivery system adopted.

\section{Concept of Trust}

In the last decades, trust has become a critical construct in socioeconomic research and in organizational practice (Rousseau et al. 1998; Bachmann 2001; McEvily et al. 2003). Trust is increasingly considered to be a key coordinating mechanism in intraorganizational and in interorganizational relationships (Nooteboom 2002). Although debates in sociology, economics, and management literature have led to a diffuse range of insights, two basic traditions can be distinguished in theorizing on trust (Janowicz-Panjaitan and Noorderhaven 2009; Lindenberg 2000). On the one hand, trusting someone can be conceptualized as calculated risk taking (Axelrod 1984; Williamson 1985, 1993), whereas on the other hand, trust can be considered as a social, more intuitive phenomenon, that is not based on calculation (Granovetter 1985; Shapiro 1992; Gambetta 1998; Gulati 1995). A similar distinction is made by Kanawattanachai and Yoo (2002), who make a distinction between cognition-based and affect-based trust. Cognition-based trust refers to calculative and rational characteristics demonstrated by trustees. Affect-based trust involves the emotional elements and social skills of trustees.

Trust concerns the expectancy that the one who is trusted will abstain from opportunistic behavior. A trustor trusts a trustee if the trustor believes that (short-term) temptations to defect will not lead to reductions in the trustee's reliability (Lindenberg 2000). By the act of trusting, the trustor assumes a position of vulnerability and is delivered to the consequences of acts of the trustee because the behavior of the trustee contains elements of unpredictability and uncertainty (Chiles and MacMackin 1996).

Many authors (e.g., Shapiro et al. 1992; Klein Woolthuis et al. 1999, 2005; Nooteboom 1996) put forward the idea that interorganizational trust can exist at different levels. A distinction between the levels of trust is made by Klein Woolthuis (1999). The first level is trust propensity. According to this author, people have a basic attitude toward other persons that contains a general willingness to trust. This basic attitude differs among individuals as a result of past experiences, cultural backgrounds, and other social settings in which they operate. When people begin a relationship, this level can be considered as given. The second level of trust is based on knowledge concerning specific other persons: Cognition- or knowledge-based trust, as defined by Shapiro et al. (1992). This type of trust is based on knowledge of the partner's competences and capabilities and the partner's tendency to abstain from opportunistic behavior. The third level of trust, affect-based trust, is reached when people develop feelings about the other that make them trust. It is based on care, concern, honesty, and understanding. These three levels of trust could be characterized as a "conscious choice to be vulnerable" (Klein Woolthuis 1999). Often, a fourth level is distinguished that does not involve a conscious choice: The concept of habituation or routine-based trust (Nooteboom 1996).
Trust is then developed when actors are so used to each other's working procedures that they do no longer realize that they are vulnerable.

\section{Trust in Project-Based Industries}

Meyerson et al. (1996) were among the first scholars to think about the properties of interorganizational trust in temporary groups. These authors stated that processes of trust development in this context may differ from conventional forms of trust development because team members are more inclined to import expectations of vulnerability and risk from comparable settings with which they are familiar than to develop trust by personal interaction: "[B] ecause there is insufficient time for expectations to be built from scratch, they tend to be imported from other settings" (Meyerson et al. 1996). Hence, a certain level of trust already may exist at the start of a relationship (see McKnight 1998). Participants import expectations of trust from comparable settings with which they are familiar (Kanawattanachai and Yoo 2002; Jarvenpaa and Leidner 1999). Importing expectations is a pragmatic strategy for dealing with uncertainty and risk in a project-based industry that enables business partners to perform complex tasks adequately, making use of the specialized skills of relative strangers. Moreover, prior experiences with a specific other, and expectations regarding future interactions may also form a basis for trust (McAllister 1995; Rousseau et al. 1998; Axelrod 1984). The same is true of the tender procedure followed before the start of the project and the delivery system adopted (Kadefors 2004; Lui and Ngo 2004; Zaghloul and Hartman 2003). These various sources of trust will be discussed in subsequent paragraphs.

First, the development of trust is primarily influenced by activities in the past and by future expectations. Prior experiences play an important role in determining if and to what extent a partner can be trusted. Cognition-based, affect-based, and routine-based trust are all influenced by previous experiences with the partner. Through recurrent interactions, parties acquire knowledge of each other. However, trust is also determined by the future expectations. The way people trust each other strongly depends on the expectation that they will need each other in the future (Axelrod 1984). Trust based on the continuation of a long-term, successful relationship is often called calculus-based trust (McAllister 1995; Rousseau et al. 1998). This involves conscious predictions of the other's trustworthiness on the basis of former contact and also prospects of future exchange.

Second, it has also been stated that trust is strongly influenced by the tender procedure used and the contract form or delivery system adopted (Kadefors 2004; Lui and Ngo 2004; Zaghloul and Hartman 2003). The tender procedure and form of the contract together determine the course of the process and the contractors' strategic behavior during the rest of the project (e.g., Ewerhart and Fieseler 2003). A principal can use different procurement systems. It is possible to choose one contractor (invited tendering), a selected number of contractors (short listing), or to invite contractors to sign up for the project in a public tendering procedure. An important consideration is the relationship between the procurement system chosen and the level of trust between principal and contractor. One can imagine that in the case of invited tendering, the principal has a strong trust in the contractor invited on the basis of past experiences.

A principal can also use different contracts. A majority of the contracts are variants of simple fixed-price and cost-plus contracts (Bajari and Tadelis 2001; Twort and Rees 2004). The primary trade-off between these contract types is flexibility versus incentives (Crocker and Reynolds 1993). Fixed-price contracts provide strong cost-minimization incentives for the agent but raise the 
chance of hold-up when the contract has to be renegotiated. Costplus contracts provide flexibility but create no incentive for costminimization because the agent is fully reimbursed for its costs. Empirical results suggest that as repeated contracting becomes more important, the principal increasingly chooses to use a flexible cost-plus contract and to trust the agent to work efficiently (Corts 2009; Ewerhart and Fieseler 2003).

A fixed-price or a cost-plus contract can both be implemented under different relationship schemes between the designers and contractors. The level of separation between design and construction is of special interest when analyzing the level of trust between principal and contractor organizations. In traditional delivery systems, design and execution responsibilities are strictly separated. Designing and constructing parties have separate contracts with the client. Delivery systems that integrate design and construction are the construction team and design-build contracts. In a construction team, the principal, the architect, several advisers, and one or more executing building companies discuss the design and execution. In a design-build contract, one organization is responsible for both the design and the construction.

As the brief discussion in the previous paragraph indicates, many forms of trust can be distinguished, and there have been studies of various aspects of trust in the context of the construction industry. However, so far, systematic research looking at different factors simultaneously influencing trust has been lacking. A major objective of this study is therefore to explore to what extent the level of trust between the principal and contractor organizations of construction projects varies according to the history of working together and the prospects of working together again, the tender procedures used, and the delivery systems adopted. First, in the specific project-based context of the construction industry, it is crucial to see how levels of trust in construction projects vary according to the history of working together and the prospects of working together again. It has been suggested that both past and future cooperations leave strong imprints on the level of trust in interorganizational relationships (Larson 1992; Klein Woolthuis 1999), and it is important to see if this bears out in construction projects. Further, because it has been stated that trust in construction is strongly influenced by the tender procedure and the delivery system used (Latham 1994; Egan 1998), it is also interesting to see how the level of trust varies according to the way the project is put out to tender and to the type of contract adopted by the organizations involved. This study explores these issues by means of a survey among principal and contractor organizations, which allows the authors to gauge differences between the perspectives of the two sides involved in construction projects. This is important because studies on trust based on empirical data are rare in the construction management literature and because it is important to study whether trusting, cooperative relationships will develop in one-off projects or require a project-exceeding process of cultural change that can only develop over a longer period of time (Bresnen 2007). This survey will be discussed in the next section.

\section{Data and Methods}

\section{Survey Data Collection}

A questionnaire was designed to explore how levels of trust in construction projects vary according to prior experiences, prospects of future exchange, the tender procedure used, and the delivery system adopted. Data were collected using a large-scale sample of both principal organizations and contractor organizations. A database of Dutch construction projects put out to tender was acquired, including addresses of both the principal organizations and the contractor organizations involved. A package containing the questionnaire, a cover letter, and a prepaid return envelope was sent to a sample of 739 principal organizations and 745 contractor organizations. A replacement survey was sent to the nonrespondents of both groups four weeks after the first mailing. The principal organizations returned 135 usable, completed questionnaires, constituting an $18.3 \%$ response rate. The contractor organizations returned 202 usable questionnaires, a $27.1 \%$ response rate. Overall, the response rate of both samples was $22.7 \%$, which is deemed to be an acceptable level (see Harzing 1997). The sample of principals included both private and public organizations, and the sample of contractors included firms working on both buildings and on infrastructure.

The questionnaire was directed to the boards of the principal organizations and contractor organizations. In the cover letter, a concise description and the precise location of a specific project was given. The board was asked to ensure that the project manager involved was given the opportunity to complete the questionnaire. The project managers of the principal organizations were asked to respond to questions about their trust in the contractor organization involved and vice versa. Furthermore, questions regarding some specific situational variables were included. Project managers were selected as the appropriate respondents because they occupy the boundary-spanning position connecting the organizations they work for with their project partner firms (Ring and Van de Ven 1994; Nooteboom 2002; Janowicz and Noorderhaven 2006). The questionnaire was proofread by several scholars, some experienced in the survey method and some knowledgeable with respect to the trust debate or the features of the construction industry. Subsequently, the questionnaire was tested on researchers in the field of construction management to assure the relevance and understandability of the questions and the appropriateness of the response scales.

\section{Survey Data Analysis}

The authors used Statistical Package for Social Sciences (SPSS) to analyze our data set. The authors explored the levels of trust expressed by respondents, and the relationships between levels of trust and prior experiences, the prospects of future exchange, the tender procedure used, and the delivery system adopted. Several analysis methods were used. To examine whether the means of two different groups for a specific variable were equal, $t$-test statistics were used. To test whether the means of three (or more) groups were equal, analyses of variance statistics were used. Because when comparing multiple groups it was also interesting to know which groups differ from each other, multiple comparison test statistics were used. Both $t$-tests and analyses of variance statistics require data derived from a random sample with a normally distributed population. Therefore, diagnostic tests were performed to ascertain that the data conformed to the characteristics of a normal distribution. To examine whether two variables vary together, a correlation analysis was used, with $t$-test statistics to gauge significance of the correlation. To examine whether a relationship between a dependent variable and two or more independent variables was linear, multiple regression analysis was used.

\section{Survey Operationalization}

Trust is a complex phenomenon. Therefore, it is difficult to fully capture the multidimensional trust phenomenon with a survey. To form a notion of the levels of trust within construction projects that was as complete as possible, the project managers of both the principal and contractor organizations were asked to respond to 10 propositions by giving them a score between 1 and 10. These propositions reflect an atmosphere of trust or distrust in the relationship 
with the other party (see the appendix). The propositions were derived from an earlier questionnaire on atmospheres of trust within interorganizational relationships and based on the levels of trust discussed by Klein Woolthuis (1999). A trusting atmosphere is represented by an emphasis on those characteristics that are assumed to positively contribute to the relationship, such as concern, honesty, understanding, habituation, disclosure of information, and sharing of feelings and criticism. Convergent validity of the trust scale formed from the 10 propositions was assessed by means of Cronbach'a alpha coefficients. For both the principal and contractor samples, alpha reliability was excellent $(0.933$ and 0.945 , respectively). This indicates that the 10 statements can indeed be combined into a single scale. The trust scale used in the analyses is simply the mean of the answers a respondent gives to the 10 statements, with a theoretical minimum of 1 and a theoretical maximum of 10 .

Further, to explore how the level of trust in construction projects varies according to prior experiences, the prospects of future exchange, the tender procedure used, and the delivery system adopted, several independent variables were also included in the questionnaire. First, the focus was on the specific project-based context of the construction industry. In this regard, first and foremost, it was interesting to see how the levels of trust in construction projects varied according to the history of working together or prior experiences, and the prospects of working together again in the future. This is because it has been suggested that both past and future cooperations leave strong imprints on the level of trust in interorganizational relationships (Larson 1992; Klein Woolthuis 1999). The questions were derived from an earlier questionnaire on the influence of project-exceeding cooperation on the performance of interorganizational relationships in construction (Welling 2006). Further, because it has been stated that trust in construction is strongly influenced by tender procedures used, and by the delivery system used (Latham 1994; Egan 1998), it was also interesting to see how the level of trust varies according to the way the project is put out to tender and the delivery system adopted by the organizations involved (for the exact questions used, see the appendix).

\section{Common-Method Bias}

Because all of the variables were measured using the same instrument, the authors checked for the possibility of common-method bias influencing the findings. In a first step, the authors performed a factor analysis on all the perceptual variables used in the analysis (see Podsakoff and Organ 1986). This analysis was restricted to the 10 trust items and the eight items measuring perceptions of past experiences and future expectations because the questions regarding the delivery system and tender procedure are factual, and not perceptual and because these are categorical variables that do not lend themselves to factor analysis. For neither of the two data sets (principals and contractors) did the factor analysis indicate the existence of a single background factor that could be seen as an indication of common-method bias. For the principal data, the authors found four factors with eigenvalues greater than 1 , with the first factor explaining only $38 \%$ of the variance. For the contractor data, the authors found three factors with eigenvalues greater than 1 , with the first factor accounting for $43 \%$ of the variance. In both cases, the trust items loaded on the first factor and the items regarding past and future cooperation on the other factors. In a second step, followed Lindell and Whitney's (2001) procedure was followed and checked for common-method variance by introducing a marker variable. A marker variable should be measured by the same instrument as the variables used in the analysis but should theoretically be unrelated to the variables of interest. "Information exchange beyond the project" was selected as the marker variable; because this variable was not used analyses, there seemed to be no theoretical reason to assume a relationship with any of the variables of interest, and the marker variable was measured in the same way as most of the other variables. The authors checked the partial correlations between the eight variables measuring past and future cooperation on the one hand and the trust scale on the other. Before controlling for information exchange beyond the project, five out of eight correlations for the principal data and seven out of eight for the contractor data were significant at the 5\% level. After controlling for information exchange beyond the project, these numbers dropped to three out of eight (principals) and six out of eight (contractors). In all cases, the sign of the correlation remained identical even if it dropped below significance in some cases. On the basis of these checks, the authors conclude with some caution that common-method variance does not seem to play an important role in the findings.

The authors will now turn to our findings, starting with the effect of prior experiences and future expectations on the level of trust in a project.

\section{Project-Exceeding Cooperation}

In this section, the influence of the history of working together and the prospects of working together again on the levels of trust within construction projects is discussed. In the questionnaire, the project managers were first asked whether they or their organization worked together in the past with the other organization or with its project manager. Furthermore, the project managers were asked whether they or their organization expected to work together again with the other organization or with its project manager.

\section{Principal Organizations}

In Table 1, the answers of the project managers of principals on the questions about the working history are presented. The table shows a comparison of the mean levels of trust (on the basis of the 10 statements discussed previously) for various subgroups of respondents. The data demonstrate that in the majority of cases, the principal organization has a working history with the organization of the contractor. However, if one looks at previous relations at the interpersonal level (project manager principal to project manager contractor), one sees see that this was true only in a minority of cases (42 out of 122). The data show that for the level of trust within construction projects, it makes a significant difference if the project managers of the principal personally worked together in the past with the contractor organization and with its project manager. Therefore, from the perspective of the principal organization, it appears that the former personal experiences of project managers are of special importance with regard to the level of trust present within a construction project.

In Table 2, the level of trust expressed is related to the answers to the questions about the prospects of working together again give by the project managers of principals. The table shows that it makes a difference for the level of trust within a construction project if the organization of the principal or its project manager expect to work together again with the organization of the contractor or with its project manager. The data demonstrate that in a majority of cases, the respondent expects to work again with the same contractor, either personally or at least with the contractor's organization. The expectation that the two project managers will personally work together again is understandably lower. Future expectations clearly matter for the level of trust expressed by the project managers of the principals. In all cases, there is a positive association between future prospects and trust, and in three of the four cases, the difference 
Table 1. Influence of the History of Working Together in the Past on the Levels of Trust within Construction Projects: A Principal Organization Perspective

\begin{tabular}{|c|c|c|c|c|}
\hline Type of principal-contractor relation & Working history $^{\mathrm{a}}$ & Mean trust & SD & Significance \\
\hline \multirow[t]{2}{*}{ Organization principal-organization contractor } & Yes $(n=88)$ & 7.06 & 1.57 & \multirow[t]{2}{*}{0.454} \\
\hline & No $(n=39)$ & 7.09 & 1.22 & \\
\hline \multirow[t]{2}{*}{ Organization principal-project manager contractor } & Yes $(n=55)$ & 6.99 & 1.76 & \multirow[t]{2}{*}{0.271} \\
\hline & No $(n=71)$ & 7.16 & 1.25 & \\
\hline \multirow[t]{2}{*}{ Project manager principal-organization contractor } & Yes $(n=67)$ & 7.42 & 1.44 & \multirow[t]{2}{*}{$0.005^{\mathrm{b}}$} \\
\hline & No $(n=60)$ & 6.74 & 1.46 & \\
\hline \multirow[t]{2}{*}{ Project manager principal-project manager contractor } & Yes $(n=42)$ & 7.48 & 1.65 & \multirow[t]{2}{*}{$0.034^{\mathrm{b}}$} \\
\hline & No $(n=80)$ & 6.93 & 1.40 & \\
\hline
\end{tabular}

${ }^{\mathrm{a}}$ Total numbers of relationships differ between rows because of missing answers.

${ }^{\mathrm{b}}$ Significant at the $5 \%$ level.

Table 2. Influence of the Prospects of Working Together Again on the Levels of trust in Construction Projects: A Principal Organization Perspective

\begin{tabular}{|c|c|c|c|c|}
\hline Type of principal-contractor relation & Future prospects ${ }^{\mathrm{a}}$ & Mean trust & SD & Significance \\
\hline \multirow[t]{3}{*}{ Organization principal-organization contractor } & Yes $(n=91)$ & 7.34 & 1.45 & $0.037^{\mathrm{b}}$ \\
\hline & No $(n=1)$ & 7.20 & - & \\
\hline & Unknown $(n=39)$ & 6.61 & 1.46 & \\
\hline \multirow[t]{3}{*}{ Organization principal-project manager contractor } & Yes $(n=61)$ & 7.42 & 1.56 & 0.078 \\
\hline & No $(n=4)$ & 6.78 & 1.60 & \\
\hline & Unknown $(n=61)$ & 6.82 & 1.39 & \\
\hline \multirow[t]{3}{*}{ Project manager principal-organization contractor } & Yes $(n=83)$ & 7.40 & 1.48 & $0.004^{\mathrm{b}}$ \\
\hline & No $(n=7)$ & 7.51 & 0.84 & \\
\hline & Unknown $(n=41)$ & 6.50 & 1.39 & \\
\hline \multirow[t]{3}{*}{ Project manager principal-project manager contractor } & Yes $(n=59)$ & 7.46 & 1.53 & $0.031^{\mathrm{b}}$ \\
\hline & No $(n=9)$ & 6.99 & 1.21 & \\
\hline & Unknown $(n=59)$ & 6.75 & 1.42 & \\
\hline
\end{tabular}

${ }^{\mathrm{a}}$ Total numbers of relationships differ between rows because of missing answers.

${ }^{\mathrm{b}}$ Significant at the $5 \%$ level.

is statistically significant. Of course, the authors cannot conclude unequivocally that future prospects lead to more trust because the opposite causality is also plausible: Principals are more likely to work again in the future with contractors whom they trust.

\section{Contractor Organizations}

Table 3 shows the answers to the questions about the working history given by the project managers of contractor organizations. As with the principal organizations, in the majority of cases, the project managers of the contractors reported that there have been previous projects between the principal and the contractor organizations, but only in a minority of cases ( 73 out of 118 ) had the project manager of the contractor worked together personally with the project manager of the principal. The importance of a personal link stands out even more clearly in these data than in those reflecting the point of view of the principal. In all cases in which there had been a personal link in previous projects, the level of trust expressed is significantly higher than incases in which this was not the case. Therefore, from a contractor organization perspective, the working history of the project managers themselves and a prior involvement of the project manager of the principal organization appears to be of special importance with regard to the level of trust actually present within a construction project.

The answers to the questions about the prospects of working together again, given by the project managers of contractor organizations are presented in Table 4 . The data show that an overwhelming majority of the contractors expects to work again with the principal organization; this is also true if examined at.the interpersonal level: 131 (out of 188) of the respondents believes that they will personally work together again in the future with the same

Table 3. Influence of the History of Working Together in the Past on the Levels of Trust within Construction Projects: A Contractor Organization

\begin{tabular}{|c|c|c|c|c|}
\hline Type of principal-contractor relation & Working history $^{\mathrm{a}}$ & Mean trust & $\mathrm{SD}$ & Significance \\
\hline \multirow[t]{2}{*}{ Organization contractor-organization principal } & Yes $(n=134)$ & 7.30 & 1.63 & \multirow[t]{2}{*}{0.168} \\
\hline & No $(n=56)$ & 7.03 & 1.83 & \\
\hline \multirow[t]{2}{*}{ Organization contractor-project manager principal } & Yes $(n=96)$ & 7.55 & 1.50 & \multirow[t]{2}{*}{$0.002^{\mathrm{b}}$} \\
\hline & No $(n=92)$ & 6.85 & 1.80 & \\
\hline \multirow[t]{2}{*}{ Project manager contractor-organization principal } & Yes $(n=100)$ & 7.51 & 1.63 & \multirow[t]{2}{*}{$0.007^{\mathrm{b}}$} \\
\hline & No $(n=93)$ & 6.91 & 1.68 & \\
\hline \multirow[t]{2}{*}{ Project manager contractor-project manager principal } & Yes $(n=73)$ & 7.78 & 1.46 & \multirow[t]{2}{*}{$0.000^{\mathrm{b}}$} \\
\hline & No $(n=118)$ & 6.86 & 1.71 & \\
\hline
\end{tabular}

${ }^{\mathrm{a}}$ Total numbers of relationships differ between rows because of missing answers.

${ }^{\mathrm{b}}$ Significant at the $5 \%$ level. 
Table 4. Influence of the Prospect of Working Together Again on the Levels of Trust in Construction Projects: A Contractor Organization Perspective

\begin{tabular}{|c|c|c|c|c|}
\hline Type of principal-contractor relation & Future prospects ${ }^{\mathrm{a}}$ & Mean trust & SD & Significance \\
\hline \multirow[t]{3}{*}{ Organization contractor-organization principal } & Yes $(n=171)$ & 7.35 & 1.67 & \multirow[t]{3}{*}{$0.003^{\mathrm{b}}$} \\
\hline & No $(n=0)$ & - & - & \\
\hline & Unknown $(n=19)$ & 7.23 & 1.38 & \\
\hline \multirow[t]{3}{*}{ Organization contractor-project manager principal } & Yes $(n=138)$ & 7.54 & 1.53 & \multirow[t]{3}{*}{$0.000^{\mathrm{b}}$} \\
\hline & No $(n=4)$ & 6.10 & 3.52 & \\
\hline & Unknown $(n=47)$ & 6.36 & 1.57 & \\
\hline \multirow[t]{3}{*}{ Project manager contractor-organization principal } & Yes $(n=160)$ & 7.41 & 1.63 & \multirow[t]{3}{*}{$0.001^{\mathrm{b}}$} \\
\hline & No $(n=3)$ & 6.87 & 0.55 & \\
\hline & Unknown $(n=26)$ & 6.08 & 1.64 & \\
\hline \multirow[t]{3}{*}{ Project manager contractor-project manager principal } & Yes $(n=131)$ & 7.62 & 1.45 & \multirow[t]{3}{*}{$0.000^{\mathrm{b}}$} \\
\hline & No $(n=9)$ & 6.61 & 2.25 & \\
\hline & Unknown $(n=48)$ & 6.17 & 1.67 & \\
\hline
\end{tabular}

Total numbers of relationships differ between rows because of missing answers.
${ }^{\mathrm{b}}$ Significant at the $5 \%$ level.

project manager of the principal organization. Again, a very strong association can be seen between future expectations and the level of trust expressed in the present project (highly significant in all four rows in Table 4). As mentioned previously, conclusions cannot be drawn regarding a causal link, but clearly, the association between trust and future expectations is particularly strong for project managers of contractors. Therefore, from a contractor organization perspective, the future prospects, both on the organizational and project manager level, are of special importance regarding the level of trust actually present within a construction project.

\section{Tender Procedure and Delivery System}

In this section, the influence of the tender procedure used and delivery system adopted, on the levels of trust within construction projects is discussed. In the questionnaire, the project managers were asked if the project they were working on had been put out to tender by invited tendering, open competitive tendering without short listing, open competitive tendering with short listing, or negotiated tendering. The project managers were also asked whether the project they were working on was being built by a traditional delivery system of contract, a turn-key type of arrangement, a public-private partnership, a construction team form of contract, or a design-build type of arrangement.

\section{Principal Organizations}

Tables 5 and 6 tabulate the answers provided by project managers from the principal organizations. In the vast majority of the cases studied, there had not been an open tendering procedure. Traditional contracts are predominant, although the construction team setup is also used frequently. Although there are some slight

Table 5. Influence of the Tender Procedure on the Levels of Trust in Construction Projects: A Principal Organization Perspective

\begin{tabular}{lcccc}
\hline Tender procedure & $\begin{array}{c}\text { Number of } \\
\text { cases }\end{array}$ & $\begin{array}{c}\text { Mean } \\
\text { trust }\end{array}$ & SD & Significance \\
\hline $\begin{array}{l}\text { Invited tendering } \\
\text { Open competitive tendering }\end{array}$ & $\begin{array}{c}(n=54) \\
(n=7)\end{array}$ & 7.06 & 1.68 & 0.99 \\
$\begin{array}{l}\text { without short listing } \\
\begin{array}{l}\text { Open competitive tendering } \\
\text { with short listing }\end{array}\end{array}$ & $(n=12)$ & 7.01 & 1.03 & \\
$\begin{array}{l}\text { Negotiated tendering } \\
(n=61)\end{array}$ & 7.25 & 1.40 & \\
\hline
\end{tabular}

differences in the level of trust across the different tendering procedures and delivery systems, these differences are nowhere near significant. Hence, it can be concluded that from the perspective of the principal organization trust in the contractor does not vary with tendering procedure or the delivery system used. A reason might be that in many cases, the project manager from the principal will not personally be involved in the tendering and contracting procedures (in the case of public principal organizations, this tends to be avoided). The project manager steps in after the tendering procedure and the contracting phase have been concluded. The project manager's level of trust consequently is not influenced by these factors.

\section{Contractor Organizations}

The project managers of the contractors were also asked about the tendering procedures and the delivery systems. Tables 7 and 8 show that according to these respondents, open competitive tendering procedures were used only in a minority of cases and that

Table 6. Influence of the Delivery System on the Levels of Trust in Construction Projects: A Principal Organziation Perspective

\begin{tabular}{lcccc}
\hline Delivery system & Number of cases & Mean trust & SD & Significance \\
\hline Traditional & $(n=66)$ & 7.06 & 1.41 & 0.233 \\
Turn-key & $(n=4)$ & 5.75 & 2.29 & \\
PPP & $(n=1)$ & 6.80 & - & \\
Construction team & $(n=52)$ & 7.29 & 1.50 & \\
Design-build & $(n=7)$ & 7.99 & 1.17 & \\
Other & $(n=3)$ & 6.80 & 1.10 & \\
\hline
\end{tabular}

Table 7. Influence of the Tender Procedure on the Levels of trust in Construction Projects: A Contractor Organziation Perspective

\begin{tabular}{lcccc}
\hline Tender procedure & $\begin{array}{c}\text { Number of } \\
\text { cases }\end{array}$ & $\begin{array}{c}\text { Mean } \\
\text { trust }\end{array}$ & SD & Significance \\
\hline $\begin{array}{l}\text { Invited tendering } \\
\text { Open competitive tendering, }\end{array}$ & $(n=68)$ & 7.66 & 1.48 & $0.001^{\mathrm{a}}$ \\
$\begin{array}{l}(n=21) \\
\text { without short listing }\end{array}$ & 6.86 & 1.62 & \\
$\begin{array}{l}\text { Open competitive tendering, } \\
\text { with short listing }\end{array}$ & $(n=25)$ & 6.14 & 1.32 & \\
$\begin{array}{l}\text { Negotiated tendering } \\
\text { Nen }\end{array}$ & & & & \\
\hline
\end{tabular}

${ }^{\mathrm{a}}$ Significant at the $5 \%$ level. 
Table 8. Influence of the Delivery System on the Levels of Trust in Construction Projects: A Contractor Organization Perspective

\begin{tabular}{lcccc}
\hline Delivery system & Number of cases & Mean trust & SD & Significance \\
\hline Traditional & $(n=117)$ & 6.91 & 1.71 & $0.016^{\mathrm{a}}$ \\
Turn-key & $(n=8)$ & 8.43 & 1.20 & \\
PPP & $(n=0)$ & - & - & \\
Construction team & $(n=63)$ & 7.55 & 1.54 & \\
Design-build & $(n=6)$ & 7.42 & 1.36 & \\
Other & $(n=1)$ & 9.00 & - & \\
\hline
\end{tabular}

${ }^{a}$ Significant at the $5 \%$ level.

traditional contracts and construction team contracts were most prevalent. However, in contrast with the project managers of the principal, these respondents did express significantly different levels of trust depending on the tendering procedure and the delivery system. Not surprisingly, contracts that have gone through open competitive tender procedures were associated with lower levels of trust. With regard to delivery system, traditional contracts are associated with lower levels of trust than, turn-key projects and construction teams, for example. Competitive tendering procedures tend to lead to an adversarial starting relationship between contractor and principal, and traditional contracts tend to aggravate this (see, e.g., Dainty et al. 2001). Why are these effects found in in the answers of the project managers from the side of the contractors and not in those from the side of the principal organizations? A possible explanation might be that project managers at contractor firms are more involved in and/or better informed about the tendering process. There is no potential conflict of interest that would compel their organizations to avoid this. Another possible explanation could be that the tendering procedure and (to a large extent) also the delivery system are selected by the principal. Open competitive tendering and traditional contracts may be perceived by contractors as signs of low trust from the side of the principal and may be responded to in kind. In contrast, from a contractor perspective, nontraditional contracts may serve as a sign of and a base for trust creating room for benevolent behavior.

\section{Discussion}

A major objective of this study was to explore to what extent levels of trust between principal and contractor organizations of construction projects vary with prior experiences and future prospects, the tender procedures, and the delivery system (see Fig. 1). The results of the survey are discussed in this order.

\section{Prior Experiences and Future Prospects}

The focus of this study is on the specific project-based context of the construction industry. Within this context, firms are working on temporary projects in constantly changing coalitions. These

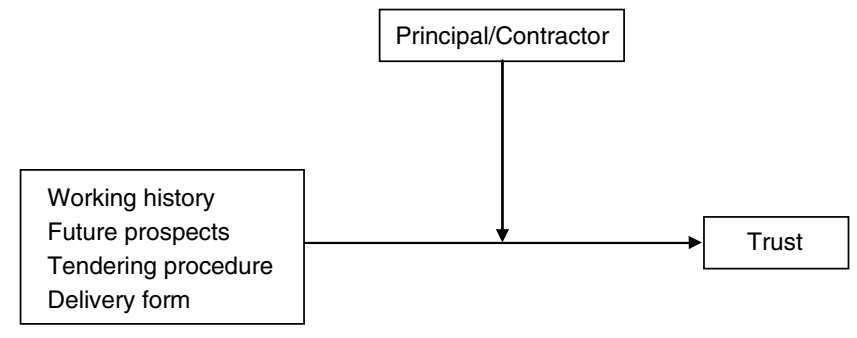

Fig. 1. Antecedents and moderators of trust in construction projects characteristics hinder the ability of team members to gain mutual experience and to develop predictability regarding each other's actions, which are necessary to define and possibly widen reliability borders. In other words, the temporal character of projects complicates the development of trust in construction. Therefore, it comes as no surprise that construction project coalitions are often criticized for a lack of trust and cooperation (Kadefors 2001; Cheung et al. 2003). Given the importance of trust for interorganizational collaboration (e.g., Brock Smith and Barclay 1997), the authors analyzed in this study the ways in which levels of trust in construction projects vary with some factors that are (at least to some extent) under the control of the principals and/or contractors, namely, previous experiences, the prospect of future projects, the tendering procedure used, and the delivery system employed.

The data show that within the construction industry, perceptions of project-exceeding cooperation between the principal and contractor organizations not only on the organizational level but also on the project manager level strongly influence the level of trust in a construction project. With regard to the working history, it appears that the personal involvement of project managers is of significant influence on the levels of trust in construction projects. With regard to the prospects of working together again in the future, it appears that an expected future cooperation on an organizational level also has a significance influence on the level of trust in a construction project. The suggestion that both past experience and future prospects leave strong imprints on the level of trust in interorganizational relationships (Larson 1992; Klein Woolthuis 1999) is confirmed in this study. The past is seen as important because it gives strong leads to the reasons why a partner is chosen and why partners become willing to cooperate. In the phase in which preconditions for exchange are created and conditions on which to build a relationship are formed, personal reputations, prior exchange relationships, and firms' reputations play crucial roles. Further more, in the phase in which the relationship is operational, the development of a trusting atmosphere is seen to be as important as mutual economic advantage: "[T]he integrity of participants, their honesty and their continued efforts to improve the exchange process became important ingredients of the process as firms took incremental risks and invested more in the relationship" (Larson 1992). Finally, future prospects also play an important role, especially when a relationship is ending. Klein Woolthuis (1999) found that " $[\mathrm{I}] \mathrm{f}$ the active, operational relationship between partners is ended because of the joint project has been completed, this does not imply that the relationship is broken." Partners who have already built a joint exchange history may prefer to cooperate with such partners if new projects are to be started. This continuation may be extrinsically valued on the basis of business complementarities and jointly achievable opportunities. It may also be intrinsically valued on the basis of the continuation of a satisfactory relationship.

\section{Tender Procedure and Delivery System}

It has been stated that trust in construction is strongly influenced by the tender procedure and the delivery system used (Latham 1994; Egan 1998). Delivery systems define the flow of control. The relationship between control and trust is complicated. A large body of literature exists about this relationship (Klein Woolthuis et al. 2005; Poppo 2002; Reed 2001; Das and Teng 2001; Knights et al. 2001). Basically, two contradictory views on the relationship between the two concepts exist: The substitute perspective and the complementary perspective (e.g., Van de Ven and Ring 2006; Vlaar et al. 2007; Costa and Bijlsma-Frankema, 2007). The substitution perspective suggests that trust and control are inversely related, implying that contracts will result in less trust and vice versa (e.g., Gulati 1995; 
Das and Teng 2001; Inkpen and Currall 2004). The complementary perspective suggests that trust and control are mutually reinforcing in counteracting internal and external risks, implying that contracts will result in more trust and vice versa (e.g., Zaheer and Venkatraman 1995; Poppo and Zenger 2002; Luo 2002). Some scholars have tried to resolve this discussion as to whether trust and control complement or substitute for each other. By focusing on how business partners arrive at positive expectations of each other, Möllering (2005), for instance, states that "trust and control assume the existence of the other, refer to each other and create each other, but remain irreducible to each other." Speaking of trust and control, assuming the existence of both implies that assuming the benevolence of a partner firm also assumes a "social structure to which such benevolence is recognizable, relevant and thereby shaped in a particular way. An actor who assumes that social structures have a controlling influence on others must also assume that those others will not exploit malevolently the freedom that inevitably remains" (Möllering 2005).

The results of the study show that from a principal organization perspective, the tender procedure used and the delivery system adopted do not have a significant influence on the levels of trust in construction projects. This does not hold for the contractor organizations. For these organizations, nontraditional delivery systems are associated with higher levels of trust. These contracts serve as a sign of and a base for trust (Mayer and Argyres 2004; Poppo and Zenger 2002; Sitkin 1995; Klein Woolthuis et al. 2005). This result seems to confirm the complementary perspective on the relationship between these contracts and trust. Another explanation could be that trust and control require each other's existence. This suggests that the principal and the contractor will act benevolently depending on how much room for benevolent behavior the social structure of a relationship actually leaves. Conversely, how much room for benevolent behavior the social structure leaves depends on the assumed levels of trust in the actors concerned. In this study, it can be argued that trust produces control and that control produces trust. An actor may therefore reach positive expectations of others by observing that social structures induce others to act benevolently to conform to those social structures.

A striking finding is that tendering procedure and delivery system are unrelated to trust from the perspective of the principal but are strongly related to trust from the perspective of the contractor. When reporting these findings, the authors have already briefly discussed some possible reasons for this asymmetry. To summarize, they point at possible differences in the roles of project managers at the side of the principal and at the side of the contractor with regard to tendering and contracting procedures. The authors also point at the different degrees of freedom of the principal and contractor: The principal tends to take the lead in selecting a delivery system and (even more so) a tendering procedure. These differences may lead to different levels of trust. However, overall, little is known about asymmetries in trust and trust development. Over a decade ago, Inkpen and Currall (1998) called for more research into trust asymmetry but so far, there has been little response.

\section{Conclusion}

The starting point of this study is the suggestion that project partners import expectations of trust from comparable settings with which they are familiar, such as the history of working together and the prospects of working together again, the tender procedures used, and the contracts adopted.

First, this study has shown that prior experiences and also prospects of future exchange play an important role in determining if and to what extent a partner can be trusted. Both past experiences and future prospects leave strong imprints on the level of trust in interorganizational relationships in this project-based industry. Within this industry, perceptions of project-exceeding cooperation between principals and contractors not only on an organizational level but also on an interpersonal level strongly influence the level of trust in a construction project.

Second, it has been stated that trust in construction is strongly influenced by the tender procedure used and delivery system adopted. This study has, however, shown that nontraditional delivery systems have a significant influence on the levels of trust in construction projects only from a contractor organization perspective. For these organizations, nontraditional delivery systems are associated with higher levels of trust. These delivery systems serve as a sign of and a base for trust and seem to confirm a complementary perspective on the relationship between control and trust.

A major finding of this study is the asymmetry of trust conditions between the principal and contractor: The tendering procedure and delivery system are unrelated to trust from the perspective of the principal but are strongly related to trust from the perspective of the contractor. With regard to the working history and prospects of working together again, it appears that the personal involvement of project managers is of significant influence on the levels of trust in construction projects. From a principal organization perspective, the tender procedure used and the delivery system adopted do not have a significant influence on the levels of trust in construction projects.

This study, like all studies, is characterized by a number of limitations. A first limitation is formed by the cross-sectional nature of our data. As a consequence, the (sometimes very strong) associations between levels of trust and various conditions of the project can be described, the existence of a causal relationship cannot be established with certainty. Second, a single instrument was used for collecting data regarding both the dependent variable (trust) and the independent variables (past experiences, future expectations, tendering procedure, and delivery system). This may cause singlemethod bias. However, for this particular study, the authors think this danger is small because, as the dependent variables (with the exception of prospects of future relations) are more of a factual than perceptual nature. Moreover, the checks give the authors confidence that their findings are not biased by the use of a single method. Third, there is no information concerning the outcome or performance of the projects. Although this does not invalidate the conclusions with regard to (factors associated with) the level of trust in the projects, it does mean that recommendations must be formulated very carefully. After all, the authors cannot be sure that high-trust projects are also high-performing projects. Fourth, the authors conducted this study in The Netherlands, which is characterized by a high level of general trust (Inglehart 1997). Although there is no indication that this fact changes the relationship between trust and project conditions that are the focus of this study it cannot be precluded, either. Future works could look at construction projects in a different culture or (even better) from a cross-cultural perspective.

A final limitation is related to the use of a cross-sectional survey. Trust is a dynamic phenomenon, subject to change over time under the influence of events and circumstances. The answers to the questionnaire capture the subjective perceptions of project managers at a given point in time. To the extent that these project managers make important decisions regarding their projects, these subjective understandings are exactly what should be measured because individuals act upon their interpretations of reality (Watzlawick 1990). However, the same individual could have given a different response at a 
different point in time, and other participants in the construction project could have given different answers at the same moment. The first issue calls for a more longitudinal approach. Although this data show that past and future cooperations may leave strong imprints on the level of interorganizational trust in construction projects, the data do not provide insights as to why this is the case and how project-exceeding cooperation interrelates with procurement routes chosen and delivery systems adopted both in present and in earlier construction projects. To generate these insights, longitudinal process studies are needed. The second problem would call for less subjective data. For instance, instead of asking respondents about their level of trust, behavioral trust could be the focus: the amount of risk that parties are willing to assume in a project (Mayers et al. 1995). However, such an approach would have to solve complicated questions regarding the objectification of risk.

In spite of its limitations, this study does suggest some implications for practice. To the extent that principals and contractors value high-trust relations, they should consider the advantages of repeated ties. Having worked together in the past and the prospect of working together again in the future gives a powerful boost to the level of trust in a construction project. Moreover, principals and contractors should realize that trust levels are the highest if personal relations between project managers from both sides are allowed to be continued across projects. Of course, there may be other reasons for not always allowing this to happen. Finally, principals especially should realize that the tendering method and the delivery system selected signal their levels of trust to the contractors (or at least, such as it seems to be interpreted). If a principal highly values a trusting relationship with a contractor in a particular project, open competitive tendering and a traditional contract do not provide ideal starting conditions. But again, there may be other possible overriding conditions that compel a principal to opt for a particular tendering procedure and delivery system. Future studies could profitably build on this work by delving deeper into the factors influencing trust that this study has uncovered. The authors mention three directions for future research that seem particularly promising. First of all, although trust in general has a positive effect on outcomes of interorganizational relations, this is not always the case to the same extent (Krishnan et al. 2006). Hence, it would be important in future studies to obtain also indicators of project outcomes. This would allow researchers to differentiate between situations in which trust is more related to project success to those in which trust is less related to project success. Second, studies employing a more longitudinal method could provide more clarity regarding causal relations. For instance, do previous experiences lead to higher trust in the present project between two parties, or does the present project only exist because of the trust that has been previously built? Finally, the findings with regard to the differential effects of tendering procedures and delivery systems on principals and contractors point to the importance of exploring possible asymmetries more deeply, both in levels of trust and in mechanisms leading to trust. It cannot be assumed that whatever promotes trust at the side of the principal, will also do so at the side of the contractor and vice versa. Much work remains to be done.

\section{Appendix. Questionnaires}

\section{Propositions Put to the Project Managers}

Project managers were asked to respond to the following statements about their experience with the project:
1. During this project, the contractor/principal treats problems constructively

2. I do not have the feeling of being misled by the contractor/ principal

3. The contractor/principal and I understand each other well

4. During the project, we have become accustomed to each other's working methods

5. We talk openly with each other about the interests related to this project

6. The contractor/principal provides me with information relevant to the project

7. In the relationship with the contractor/principal, I am not afraid to share information

8. Criticism can be expressed openly if this contributes to the completion of the project

9. I am loyal to the contractor/principal and the contractor/ principal is loyal to me

10. The relationship with the contractor/principal is characterized by openness

\section{Organizational Characteristics}

Respondents were asked to provide information about their organization by answering the following questions:

1. Company size in terms of turnover: millions of $€$

2. Company size in terms of employment: in Full Time Employment

\section{Project Characteristics}

Respondents were asked to provide information about the project by answering the following questions:

1. What are the total project building costs: millions of $€$ (Total sum contracted for, including extra/less work, excluding building land costs and V.A.T.)

2. Which procurement regulation was used in this project:

3. Which tender procedure was used in this project:

- Invited tendering

- Open competitive tendering

- Project-specific prequalification/short listing

- Negotiated tendering

4. Which delivery system was used in this project:

- Traditional

- Turn-key

- Public-private partnership

- Design \& Construct

- Other, namely:

\section{Mutual Trust}

Respondents were asked to what extent they agreed with the following statements about trust, using a scale of one to 10 , with one representing "Strongly disagree" and 10 representing "Strongly agree".

1. During this project, the contractor/principal treats problems constructively

2. I do not have the feeling of being misled by the contractor/ principal

3. The contractor/principal and I understand each other well

4. During the project, we have become accustomed to each other's working methods

5. We talk openly with each other about the interests related to this project

6. The contractor/principal provides me with information relevant to the project 
7. In the relationship with the contractor/principal I am not afraid to share information

8. Criticism can be expressed openly if this contributes to the completion of the project

9. I am loyal to the contractor/principal, and the contractor/ principal is loyal to me

10. The relationship with the contractor/principal is characterized by openness

\section{Prior/Future Cooperation}

Respondents were asked to respond "Yes" or "No" to the following statements about cooperation:

1. Did you cooperate with the organization of the client/ contractor in the past?

2. Did you cooperate with the project manager of the client/ contractor in the past?

3. Did your organization cooperate with the organization of the client/contractor in the past?

4. Did your organization cooperate with the project manager of the client/contractor in the past?

5. Do you expect to cooperate with the organization of this client/ contractor in the future?

6. Do you expect to cooperate with the project manager of the client/contractor in the future?

7. Do you expect that your organization will cooperate with the organization of this client/contractor in the future?

8. Do you expect that your organization will cooperate with the project manager of this client/contractor in the future?

\section{References}

Axelrod, R. (1984). The evolution of cooperation, Basic Books, New York.

Bachmann, R. (2001). "Trust, power and control in trans-organizational relations." Organ. Stud., 22(2), 337-365.

Bachmann, R., and Zaheer, A. (2006). Handbook of trust research, E. Elgar, Cheltenham, UK.

Bajari, P., and Tadelis, S. (2001). "Incentives versus transaction costs: A theory of procurement contracts." RAND J. Econ., 32(3), 387-407.

Bijlsma-Frankema, K., and Costa, A. C. (2005). "Understanding the trustcontrol nexus." Int. Sociol., 20(3), 259-282.

Bresnen, M. (2007). "Deconstructing partnering in project-based organization: Seven pillars, seven paradoxes and seven deadly sins." Int. J. Proj. Manage., 25(4), 365-374.

Brock Smith, J., and Barclay, D. W. (1997). "The effects of organizational differences and trust on the effectiveness of selling partner relationships." J. Mark., 61(1), 3-21.

Cheung, S., Thomas, S. T. N., Wong, S., and Suen, H. C. H. (2003). "Behavorial aspects in construction partnering." Int. J. Proj. Manage., 21(5), 333-343.

Chiles, T. H., and McMackin, J. F. (1996). "Integrating variable risk preferences, trust, and transaction cost economics." Acad. Manage. Rev., 21(1), 73-99.

Corts, K. S. (2009). The Interaction of implicit and explicit contracts in construction and procurement contracting, Rotman School of Management, Univ. of Toronto.

Costa, A. C., and Bijlsma-Frankema, K. (2007). "Trust and control interrelations." Group Organ. Manage., 32(4), 392-406.

Crocker, K. J., and Reynolds, K. J. (1993). "The efficiency of incomplete contracts: An empirical analysis of air force engine procurement." RAND J. Econ., 24(1), 126-146.

Dainty, R. J., Briscoe, G. H., and Millet, S. J. (2001). "Subcontractor perspectives on supply chain alliances." Constr. Manage. Econ., 19(8), 841-848.

Das, T. K., and Teng, B. S. (2001). "Trust, control and risk in strategic alliances: An integrated framework." Organ. Stud., 22(2), 251-283.
Egan, J. (1998). Rethinking construction, DETR and HMSO, London.

Ewerhart, C., and Fieseler, K. (2003). "Procurement auctions and unit-price contracts." RAND J. Econ., 34(3), 569-581.

Gambetta, D. (1998). "Can we trust trust?" Trust: Making and breaking of cooperative relations, D. Gambetta, ed., Blackwell, Oxford, UK, 213-237.

Girmscheid, G., and Brockmann, C. (2010). "Inter- and intraorganizational trust in international construction joint ventures." J. Constr. Eng. Manage., 136(3), 353-360.

Granovetter, M. S. (1985). "Economic action and social structure: A theory of embeddedness." Am. J. Sociol., 91(3), 481-510.

Gulati, R. (1995). "Does familiarity breed trust? The implications of repeated ties for contractual choice in alliances." Acad. Manage. J., $38(1), 85-112$.

Harzing, A. W. K. (1997). "Response rates in international mail surveys: Results of a 22-country study." Int. Bus. Rev., 6(6), 641-665.

Inglehart, R. (1997). Modernization and postmodernization. Cultural, economic and political change in 43 countries, Princeton University Press, NJ.

Inkpen, A. C., and Currall, S. C. (1998). "The nature, antecedents, and consequences of joint venture trust." J. Int. Manage., 4(1), 1-20.

Inkpen, A. C., and Currall, S. C. (2004). "The co-evolution of trust, control and learning in joint ventures." Organ. Sci., 15(5), 586-599.

Janowicz, M., and Noorderhaven, N. G. (2006). "Levels of interorganisational trust: conceptualization and measurement." Handbook of trust research, R. Bachmann and A. Zaheer, eds., E. Elgar, Cheltenham, UK, 264-280.

Janowicz-Panjaitan, M., and Noorderhaven, N. G. (2009). "Trust, calculation and interorganizational learning of tacit knowledge: An organizational roles perspective." Organ. Stud., 30(10), 1021-1044.

Jarvenpaa, S. L., and Leidner, D. E. (1999). "Communication and trust in global virtual teams." Organ. Sci., 10(6), 791-815.

Jin, X. H., and Ling, F. Y. Y. (2005). "Model for fostering trust and building relationships in China's construction industry." J. Constr. Eng. Manage., 131(11), 1224-1232.

Kadefors, A. (2004). "Trust in project relationships-Inside the black box." Int. J. Proj. Manage., 22(3), 175-182.

Kanawattanachai, P., and Yoo, Y. (2002). "Dynamic nature of trust in virtual teams." J. Strategic Inform. Syst., 11(3-4), 187-213.

Khalfan, M. M. A., and McDermott, P. (2007). "Building trust in construction projects." Supply Chain Manage. Int. J., 12(6), 385-391.

Klein Woolthuis, R. A. J. (1999). "Sleeping with the enemy: Trust, dependence and contracts in inter-organizational relationships." Ph.D. thesis, Twente Univ., Enschede, Nertherlands.

Klein Woolthuis, Woolthuis, R., Hillebrand, B., and Nooteboom, B. (2005). "Trust, contract and relationship development." Organ. Stud., 26(6), 813-840.

Knights, D., Noble, F., Vurdubakis, T., and Willmott, H. (2001). "Chasing shadows: Social control, virtuality and the production of trust." Organ. Stud., 22(2), 311-336.

Kramer, R. M., and Tyler, T. R. (1996). Trust in organizations: Frontiers of Theory and Research, Sage, Thousand Oaks, CA.

Krishnan, R., Martin, X., and Noorderhaven, N. G. (2006). "When does interorganizational trust matter to strategic alliance performance?". Acad. Manage. J., 49(5), 894-917.

Lane, C., and Bachmann, R. (1998). Trust within and between organizations, Oxford University Press, UK.

Larson, A. (1992). "Network dyads in entrepreneurial settings: A study of the governance of exchange relationships." Admin. Sci. Q., 37(1), 76-104.

Latham, M. (1994). Constructing the team, HMSO, London.

Lau, E., and Rowlinson, S. (2009). "Interpersonal trust and inter-firm trust in construction projects." Constr. Manage. Econ., 27(6), $539-554$.

Lindell, M. K., and Whitney, D. J. (2001). "Accounting for common method variance in cross-sectional research designs." J. Appl. Psych., 86(1), 114-121.

Lindenberg, S. (2000). "It takes both trust and lack of mistrust: The workings of cooperation and relational signaling in contractual relationships.” J. Manage. Governance, 4(1-2), 11-33. 
Lui, S. S., and Ngo, H.-Y. (2004). "The role of trust and contractual safeguards on cooperation in non-equity alliances." J. Manage., 30(4), 471-485.

Luo, Y. (2002). "Contract, cooperation and performance in international joint ventures." Strategic Manage. J., 23(10), 903-919.

Mayer, K. J., and Argyres, N. S. (2004). "Learning to contract: Evidence from the personal computer industry." Organ. Sci., 15(4), 394-410.

Mayers, R. C., Davis, J. H., and Schoorman, F. D. (1995). "An integrative model of organizational trust." Acad. Manage. Rev., 20(3), 709-734.

McAllister, D. J. (1995). "Affect- and cognition-based trust as foundation for inter-personal cooperation in organization." Acad. Manage. J., 38(1), 24-59.

McEvily, B., Perrone, V., and Zaheer, A. (2003). "Trust as an organizing principle." Organ. Sci., 14(1), 91-103.

McKnight, D. H., Cummings, L. L., and Chervany, L. (1998). "Initial trust formation in new organizational relationships." Acad. Manage. Rev., 23(3), 473-490.

Meyerson, D., Weick, K. E., and Kramer, R. M. (1996). "Swift trust and temporary groups." Trust in organizations: Frontiers of theory and research, R. M. Kramer and T. R. Tyler, eds., Sage Publications, Thousand Oaks, CA, 166-195.

Möllering, G. (2005). "The trust/control duality: An integrative perspective on positive expectations of others." Int. Sociol., 20(3), 283-305.

Nooteboom, B. (1996). "Trust, opportunism and governance: A process and control model." Organ. Stud., 17(6), 985-1010.

Nooteboom, B. (2002). Trust: Forms, foundations, functions, and failures, E. Elgar, Cheltenham, UK.

Podsakoff, P. M., and Organ, D. W. (1986). "Self-reports in organisational research: Problems and prospects." J. Manage., 12(4), 531-544.

Poppo, L., and Zenger, T. (2002). "Do formal contract and relational governance function as substitutes or as complements?" Strategic Manage. J., 23(8), 707-725.

Reed, M. I. (2001). "Organization, trust and control: A realist analysis." Organ. Stud., 22(2), 201-228.

Ring, P. S., and Van de Ven, A. H. (1994). "Developmental processes of cooperative interorganisational relationships." Acad. Manage. Rev., 19(1), 90-118.
Rousseau, D. M., Sitkin, S. B., Burt, R. S., and Camerer, C. (1998). "Introduction to special topic forum: Not so different after all: A cross-discipline view of trust." Acad. Manage. Rev., 23(3), 393-404.

Shapiro, D., Sheppard, B. H., and Cheraskin, L. (1992). "Business on a handshake." Negotiation J., 8(4), 365-378.

Sitkin, S. (1995). "On the positive effect of legalization on trust." Res. Negotiation. Organ., 5, 185-217.

Twort, A., and Rees, J. (2004). Civil engineering project management, 4th Ed., Elsevier, London.

Van de Ven, A. H., and Ring, P. S. (2006). "Relying on trust in cooperative inter-organizational relationships." Handbook of trust research, R. Bachmann and A. Zaheer, eds., Edward Elgar, Cheltenham UK, 144-164.

Vlaar, P. W. K., Van den Bosch, F., and Volberda, H. W. (2007). “On the evolution of trust, distrust and formal coordination and control in interorganizational relationships: Towards an integrative framework." Group Organ. Manage., 32(4), 407-428.

Watzlawick, P. (1990). Münchhausen's pigtail, or, Psychotherapy \& "reality": Essays and lectures, Norton, New York.

Welling, D. T. (2006). "Building on a common past towards a successful future." Ph.D. thesis, Groningen Univ., Groningen, Netherlands (in Dutch).

Williamson, O. E. (1985). The economic institutions of capitalism: Firms markets, relational contracting, Free Press, New York.

Williamson, O. E. (1993). "Calculativeness, trust and economic organization." J. Law. Econ., 36(s1), 453-486.

Wong, P. S. P., Cheung, S. O., and Ho, P. K. M. (2005). "Contractor as trust initiator in construction partnering-Prisoner's dilemma perspective." J. Constr. Eng. Manage., 131(10), 1045-1053.

Yiu, T. W., and Lai, W. Y. (2009). "Efficacy of trust-building tactics in construction mediation." J. Constr. Eng. Manage., 135(8), 683-689.

Zaghloul, R., and Hartman, F. (2003). "Construction contracts: The cost of mistrust." Int. J. Proj. Manage., 21(6), 419-424.

Zaheer, A., and Venkatraman, N. (1995). "Relational governance as An interorganizational strategy: An empirical test of the role of trust in economic exchange." Strategic Manage. J., 16(5), 373-392. 